\title{
Faktor-Faktor yang Mempengaruhi Permintaan Broiler di Kelurahan Balangnipa Kecamatan Sinjai Utara Kabupaten Sinjai
}

\author{
The Factors That Influence the Demand for Broiler in Balangnipa Village, \\ North Sinjai District, Sinjai Regency. \\ Astati ${ }^{*}$, Muh. Basir Paly \\ Jurusan Ilmu Peternakan, Fakultas Sains dan Teknologi \\ Universitas Islam Negeri Alauddin Makassar \\ *Korespondensi Email : astati@uin-alauddin.ac.id
}

\begin{abstract}
ABSTRAK
Penelitian ini bertujuan untuk mengetahui faktor-faktor yang mempengaruhi permintaan broiler di Kelurahan Balangnipa Kecamatan Sinjai Utara Kabupaten Sinjai. Penelitian ini dilaksanakan di Kelurahan Balangnipa Kecamatan Sinjai Utara Kabupaten Sinjai pada bulan Oktober 2017. Metode yang digunakan adalah metode survey yaitu dengan melakukan peninjauan dan pengamatan langsung terhadap lokasi penelitian dan aktifitas masyarakat yang ada di Kelurahan Balangnipa. Hasil penelitian menunjukkan bahwa pendapatan dan barang subtitusi merupakan faktor yang berpengaruh nyata terhadap permintaaan broiler, adapun jumlah tanggungan keluarga dan tingkat selera tidak berpengaruh nyata terhadap permintaan broiler di Kelurahan Balangnipa Kecamatan Sinjai Utara Kabupaten Sinjai.
\end{abstract}

Kata kunci : Broiler, Faktor-faktor yang Mempengaruhi, Permintaan

\begin{abstract}
This study aims to determine the factors that influence the demand for broiler in Balangnipa Village, North Sinjai District, Sinjai Regency. This research was carried out in Balangnipa Village, North Sinjai Sub-District, Sinjai District in October 2017. The method used was observation, namely by observing direct research sites and community activities in Balangnipa Village. The results showed that substitution income and goods were significant factors on broiler demand, while the number of family dependents and tastes did not affect the demand for broiler in Balangnipa Village, North Sinjai District, Sinjai District.
\end{abstract}

Keywords: Broiler, Demand, Influencing Factors

\section{PENDAHULUAN}

Usaha peternakan ayam pedaging atau biasa disebut ayam broiler komersial merupakan suatu usaha yang sangat menguntungkan. Usaha broiler menjanjikan perputaran modal yang sangat cepat, yang artinya dalam kurun waktu kurang dari satu sengah bulan, peternak broiler komersial sudah bisa mengantongi keuntungan.

Keadaan ekonomi individu yang terus membaik dan adanya kesadaran masyarakat akan arti pentingnya memelihara kesehatan tubuh melalui asupan makanan bergizi 
merupakan dua faktor utama terjadinya peningkatan jumlah permintaan konsumen terhadap daging broiler akhir-akhir ini. Maka dari hal tersebutlah yang mendorong peternak broiler terus meningkatkan populasi usahanya sehingga dapat memenuhi kebutuhan pasar akan daging broiler dengan kualitas yang baik.

Kabupaten Sinjai merupakan salah satu produsen broiler di Provinsi Sulawesi Selatan. Kawasan Kabupaten Sinjai memiliki beberapa kecamatan, salah satunya yaitu Kecamatan Sinjai Utara yang mempunyai beberapa pasar yang penjual daging broiler terbanyak di Kabupaten Sinjai, hal ini karena peternak ayam lebih memilih memasarkan daging ayam dipasar tradisional Balangnipa terbilang banyak pengunjung konsumen yang lebih memilih berbelanja di tempat tersebut karena terbilang murah dibandingkan pasar lainnya yang ada Kecamatan Sinjai Utara Kabupaten Sinjai. Berdasarkan hal di atas, sehingga dilakukan penelitian dengan judul "Faktor-Faktor yang Mempengaruhi Permintaan Broiler di Kelurahan Balangnipa Kecamatan Sinjai Utara Kabupaten Sinjai"

Berdasarkan latar belakang yang telah diuraikan diatas, maka rumusan masalahnya adalah bagaimana faktor-faktor yang dapat mempengaruhi permintaan broilerdi Kelurahan Balangnipa Kecamatan Sinjai Utara Kabupaten Sinjai. Tujuan dari penelitian ini yaitu untuk mengetahui faktor-faktor yang mempengaruhi permintaan broilerdi Kelurahan Balangnipa Kecamatan Sinjai Utara Kabupaten Sinjai. Hasil penelitian ini diharapkan dapat dijadikan sebagai sumber informasi kepada berbagai pihak terkait faktor-faktor yang mempengaruhi permintaan broilerdi Kelurahan Balangnipa Kecamatan Sinjai Utara Kabupaten Sinjai.

\section{METODE PENELITIAN}

\section{Jenis dan Lokasi Penelitian}

Penelitian ini dilaksanakan di Kelurahan Balangnipa Kecamatan Sinjai Utara Kabupaten Sinjai. Adapun alasan memilih lokasi tersebut karena lokasi tersebut merupakan daerah dengan populasi broiler lebih banyak dibanding daerah lainnya di Kecamatan Sinjai Utara Kabupaten Sinjai. Selain itu, lokasi tersebut sumberdaya alamnya mendukung untuk pengembangan usaha broiler. Penelitian ini dilaksanakan pada bulan Oktober 2017.

Jenis penelitian yang digunakan yaitu penelitian kuantitatif yang menjelaskan tentang hubungan kausal antara variabel independen (permintaan broiler) dengan variabel dependen (faktor-faktor yang mempengaruhi permintaan broliler) di Kelurahan Balangnipa Kecamatan Sinjai Utara Kabupaten Sinjai. 


\section{Sumber dan Metode Pengumpulan Data}

Populasi dalam penelitian ini yaitu konsumen ayam broiler di Kelurahan Balangnipa Kecamatan Sinjai Utara Kabupaten Sinjai yang berjumlah 550 orang. Dengan menggunakan rumus Slovin, didapatkan sampel sebanyak 80 orang. Sampel dipilih secara random sampling dengan menggunakan kriteria konsumen dengan jumlah permintaan broiler lebih dari 2 kali dalam sebulan.

Rumus Slovin sebagai berikut:

$$
\mathrm{n}=1+\frac{N}{N e^{2}} \ldots \ldots \ldots \ldots \ldots \ldots(\text { Hidayat, } 2017)
$$

Data yang diperoleh dianalisis secara statistik dengan menggunakan Regresi Linear Berganda (SPSS 20 for windows) yang bertujuan untuk mengetahui besarnya pengaruh harga broiler, pengaruh pendapatan, jumlah anggota keluarga, harga barang substitusi, dan tingkat selera terhadap permintaan broiler di Kelurahan Balangnipa Kecamatan Sinjai Utara Kabupaten Sinjai. Adapun analisis statistik yang digunakan adalah Regresi Berganda dengan persamaan sebagai berikut:

$$
Y=a+b_{1} X_{1}+b_{2} X_{2}+b_{3} X_{3}+b_{4} X_{4}+b_{4} X_{4}+b_{5} X_{5}+e
$$

Dimana:

Y

A

B

$\mathrm{X}_{1}$

$\mathrm{X}_{2}$

$X_{3}$

$\mathrm{X}_{4}$

$\mathrm{X}_{5}$

e
Permintaan broiler (ekor/bulan)

Konstanta

Koefisien regresi variabel bebas (dependent)

Pendapatan (rupiah/bulan)

Harga broiler (rupiah)

Jumlah anggota keluarga (orang)

Harga barang substitusi (rupiah)

Tingkat selera $(0=$ kurang suka, $1=$ suka $)$

Standar Error

Persamaan regresi di atas menyatakan hubungan antara independen variable (X) dengan permintaan broiler sebagai dependen variable (Y). Besarnya elastisitas bagi masingmasing varaiabel diperoleh dari koefisien regresi untuk masing-masing estimasi persamaan regresi permintaan dari faktor-faktor yang mempengaruhinya (Varian, 1992). 


\section{HASIL DAN PEMBAHASAN}

\section{Analisis Regresi Linear Berganda Faktor-faktor yang Menpengaruhi Permintaan Broiler}

Hasil estimasi dilakukan dengan analisis regresi linear berganda untuk melihat pengaruh pendapatan, harga broiler, jumlah anggota keluarga, harga barang substitusi, dan tingkat selera terhadap permintaan broiler di Kelurahan Balangnipa Kecamatan Sinjai Utara Kabupaten Sinjai. Berdasarkan Tabel 1. diperoleh fungsi permintaan broiler terhadap factorfaktor yang mempengaruhinya dengan menggunakan persamaan sebagai berikut:

$$
Y=3,816+0,190 X_{1}+0,027 X_{2}+0,051 X_{3}-0,364 X_{4}+0,0,28 X_{5}
$$

Hasil pengujian dapat dilihat pada Tabel 1. Yaitu sebagai berikut:

Tabel 1. Hasil Estimasi Faktor-faktor yang berpengaruh terhadap Permintaan Broiler di Kelurahan Balangnipa Kecamatan Sinjai Utara Kabupaten Sinjai

\begin{tabular}{lccrl}
\hline Variabel Penelitian & $\begin{array}{c}\text { Koefisien } \\
\text { Regresi }\end{array}$ & THitung $_{\text {Signifikansi }}$ & $\begin{array}{c}\text { Nilai } \\
\text { Keterangan }\end{array}$ \\
\hline Pendapatan & 0,190 & 2,553 & 0,013 & Signifikan \\
Harga broiler & 0,027 & 0,385 & 0,701 & Tidak Signifikan \\
Jumlah anggota keluarga & 0,051 & 0,732 & 0,466 & Tidak Signifikan \\
Harga barang substitusi & $-0,364$ & 6,621 & 0,000 & Signifikan \\
Tingkat selera & 0,028 & 0,445 & 0,658 & Tidak Signifikan \\
\hline $\mathrm{R}$ & $=0,434$ & & & \\
Constanta & $=3,816$ & & & \\
Adjusted R Square & $=0,396$ & & & \\
\hline Fitung & $=11,365$ & $F_{\text {Tabel }}=2,62$ & \\
$\mathrm{a}=0,000$ & & & & \\
\hline
\end{tabular}

Sumber: Hasil Analisis, 2017.

Secara parsial pengaruh masing-masing independen variable terhadap dependen variable, dilakukan dengan menggunakan uji-t. Berdasarkan hasil analisis, dapat dinyatakan bahwa pada taraf signifikansi 5\%, variabel yang signifikan terhadap permintaan broiler di Kelurahan Balangnipa Kecamatan Sinjai Utara Kabupaten Sinjai adalah pendapatan dan harga barang substitusi.

Hasil analisis diperoleh $\mathrm{R}^{2}$ sebesar 0,396 yang berarti keragaman permintaan broiler dijelaskan oleh besarnya koefisien nilai pendapatan, harga broiler, jumlah anggota keluarga, 
harga barang substitusi, dan tingkat selera adalah sebesar 39,6\%, sedangkan sisanya sebesar 29,6\% dijelaskan oleh faktor-faktor lain diluar model.

Hasil analisis ragam (analysis of varian), yakni nilai F sebesar 11,365 dengan tingkat probabilitas 0,000 (signifikansi), karena probabilitas jauh lebih kecil dari 0,05, maka model regresi dapat digunakan untuk memprediksi permintaan broiler di Kelurahan Balangnipa Kecamatan Sinjai Utara Kabupaten Sinjai atau dapat dikatakan bahwa pendapatan, harga broiler, jumlah anggota keluarga, harga barang substitusi, dan tingkat selera berpengaruh terhadap permintaan broiler di Kelurahan Balangnipa Kecamatan Sinjai Utara Kabupaten Sinjai.

Analisis Elastisitas Pengaruh Pendapatan, Harga Broiler, Jumlah Anggota Keluarga, Harga Barang Substitusi dan Tingkat Selera terhadap Permintaan Broiler di Kelurahan Balangnipa Kecamatan Sinjai Utara Kabupaten Sinjai

Besarnya perubahan permintaan broiler di Kelurahan Balangnipa Kecamatan Sinjai Utara Kabupaten Sinjai akibat perubahan salah satu faktor yang mempengaruhinya dengan asumsi cateris paribus digunakan analisis elastisitas masing-masing faktor dengan melihat koefisien regresinya. Hasil yang diperoleh dapat dijelaskan sebagai berikut:

\section{Pendapatan}

Hasil uji statistik terhadap pendapatan menunjukkan nilai koefisien sebesar 0,190. Hal ini berarti peningkatan $1 \%$ pendapatan, menyebabkan peningkatan permintaan broiler sebesar $0,190 \%$.

Pendapatan secara umum berpengaruh positif dan signifikan terhadap permintaan broiler di Kelurahan Balangnipa Kecamatan Sinjai Utara Kabupaten Sinjai. Dengan kata lain, semakin tinggi pendapatan individu, semakin besar permintaan terhadap broiler. Broiler termasuk barang normal. Barang normal atau normal goods adalah barang yang permintaannya meningkat apabila tingkat pendapatannya meningkat (Mankiw, 2008). Hal ini berarti barang barang normal adalah barang-barang yang akan meningkat jumlah permintaannya karena peningkatan pendapatan individu atau konsumen.

\section{Harga Broiler}

Koefisien regresi dari harga broiler $\left(\mathrm{X}_{2}\right)$ adalah 0,027 yang menyatakan bahwa setiap penambahan $1 \%$ harga broiler, maka permintaan broiler akan naik sebesar 0,027 . Hal ini tidak sejalan dengan hukum permintaan bahwa semakin tinggi harga, semakin menurun permintaan. 
Hasil analisis pada Tabel 1. terlihat bahwa harga broiler $\left(X_{2}\right)$ berpengaruh positif terhadap permintaan broiler. Ini berarti bahwa meskipun harga broiler tinggi, konsumen tetap membeli broiler tersebut yang dikarenakan pembelian broiler merupakan kebutuhan pada saat-saat tertentu.

\section{Jumlah Anggota Keluarga}

Jumlah angota keluarga adalah seluruh anggota keluarga yang tinggal dalam satu tempat tinggal yang membutuhkan bantuan orang lain (dalam hal ini orang tua). Hal ini diakibatkan, jumlah anggota keluarga tersebut belum mampu memenuhi kebutuhan seharihari karena belum bekerja (dalam umur non produktif).

Pada Tabel 1. Terlihat bahwa koefisien regregi dari variabel $X_{3}$ ini sebesar 0,051 yang menyatakan bahwa setiap penambahan $1 \%$ jumlah anggota keluarga, maka permintaan broiler naik sebesar 0,051. Hal ini menunjukkan, semakin bertambahnya anggota keluarga, semakin besar kebutuhan keluarga tersebut.

\section{Harga Barang Substitusi}

Barang subtitusi merupakan barang pemuas kebutuhan manusia yang saling menggantikan fungsinya dengan sempurna. Dengan kata lain apabila tidak ada barang yang satu, maka dapat digantikan dengan barang lainnya. Seperti halnya ikan dan daging ayam. Jika tidak ada ikan, maka kita bisa mengonsumsi daging ayam sebagai pemenuhan kebutuhan untuk fungsi yang sama, sehingga dalam hal ini, bisa diasumsikan jika daging ayam adalah barang substitusi dari ikan.

Dengan adanya barang substitusi, maka manusia memiliki alternatif pilihan untuk memenuhi kebutuhannya. Selain itu, kebutuhan subtitusi juga memungkinkan manusia untuk tidak perlu khawatir kekurangan barang dan jasa, karena selalu ada barang pengganti yang memiliki fungsi serupa (Utami, 2017).

Koefisien regresi dari harga barang substitusi adalah -0,364. Ini berarti setiap kenaikan 1\% harga barang substitusi, menyebabkan menurunnya permintaan barang substitusi tersebut, sehingga konsumen beralih dalam pembelian barang yang lain yang dalam hal ini, jika harga ikan naik maka konsumen melakukan pembelian terhadap barang lain yaitu daging ayam. Berbeda halnya denga penelitian yang dilakukan oleh Marlin (2013), yang menyatakan bahwa harga barang substitusi (ikan) tidak mempengaruhi pembelian daging ayam ras. 


\section{Tingkat Selera}

Hasil analisis, koefisien regresi dari variabel tingkat selera sebesar 0,028. Ini berarti setiap penambahan 1\% tingkat selera, maka permintaan broiler akan meningkat. Ini merupakan bahwa produk daging broiler merupakan salah satu bahan pangan yang sangat digemari oleh konsumen. Hal ini sejalan dengan pendapat Suantara dkk (2014), bahwa ketika selera individu meningkat terhadap suatu barang tertentu maka akan meningkatkan jumlah permintaan terhadap barang tersebut begitu pula sebaliknya, rendahnya selera konsumen terhadap suatu barang tertentu maka akan menurunkan jumlah permintaan terhadap barang tersebut.

\section{KESIMPULAN}

Berdasarkan hasil penelitian, maka disimpulkan bahwa pendapatan dan barang subtitusi merupakan faktor yang berpengaruh nyata dalam permintaan broiler namun barang substitusi mempunyai hubungan yang negatif terhadap permintaan broiler di Kelurahan Balangnipa Kecamatan Sinjai Utara Kabupaten Sinjai. Adapun harga broiler, jumlah tanggungan keluarga dan tingkat selera tidak berpengaruh terhadap permintaan broiler di Kelurahan Balangnipa Kecamatan Sinjai Utara Kabupaten Sinjai.

\section{DAFTAR PUSTAKA}

Hidayat, A. 2017. Cara Hitung Rumus Slovin Besar Sampel. https://www.statistikian.com/2017/12/hitung-rumus-slovin-sampel.html (diakses tanggal 30 Januari 2019).

Mankiw, N and Gregory. 2008. Principles of Macroeconomic. South Western Cengage Learning.

Marlin. 2013.Faktor-Faktor yang Mempengaruhi Permintaan Daging Ayam Ras pada rumah tangga di Kelurahan Gunung Sari Kecamatan Rappocini Kota Makassar.

Suantara, I.G.P.E., Made., A., dan Kadek, R.W. 2014. Pengaruh Selera dan Harga terhadap Keputusan Konsumen dalam Pembelian Sepeda Motor Honda di Kabupaten Buleleng. Jurnal Volume 4 Nomor 1.

Utami, W.A. 2017. Barang Komplementer dan Barang Substitusi, Apa Bedanya? https:// www.jurnal.id/id/blog/2017-ketahui-pengertian-barang-komplementer-danbarang-substitusi/ (diakses tanggal 30 Januari 2019).

Varian, H.R. 1992. Microeconomic Analysis. Third Edition. W.W. Norton and Company, London. 